\title{
The Internationalisation of Family Firms: the Role of the Ownership Structure and the Composition of Top Management Team
}

\author{
Aleksandra Wąsowska
}

\begin{abstract}
A B S T R A C T
Objective: The objective of this paper is to investigate the determinants of family firm internationalisation, focusing on the roles of ownership (i.e. concentration of ownership, foreign ownership) and management (i.e. involvement of nonfamily managers, owner-CEO).

Research Design \& Methods: We test our hypothesis using linear regression models and logistic regression models, based on a sample of 6,957 family firms from seven European countries (Austria, France, Germany, Hungary, Italy, Spain, UK).

Findings: The concentration of ownership within the family hinders the propensity to export, but it has no effect on export intensity and export scope. Foreign ownership contributes to firm performance and that the impact of minority foreign ownership is more pronounced than the controlling foreign ownership. The involvement of nonfamily managers enhances internationalisation, and that owner-CEO hinders internationalisation, but only in terms of global exporting.

Implications \& Recommendations: The inclusion of outsiders (both in terms of ownership and management) enhances family firms' internationalisation. This finding is particularly relevant to family business planning to expand abroad. We encourage further research investigating the relationships between different dimensions of 'familiness' and firm internationalisation, preferably in a multi-country context (e.g. advanced versus emerging economies).
\end{abstract}

Contribution \& Value Added: The originality of this work lies in treating family firms as a heterogeneous group and investigating the impact of different dimensions of 'familiness' (i.e. ownership structure, composition of TMTs) upon an internationalisation strategy.

\begin{tabular}{ll}
\hline Article type: & research paper \\
& family firms; top management team; ownership structure; interna- \\
& tionalisation; export
\end{tabular}

JEL codes: F23

\section{Suggested citation:}

Wąsowska, A. (2017). Internationalisation of Family Firms: the Role of Ownership Structure and Composition of Top Management Team. Entrepreneurial Business and Economics Review, 5(1), 169-185, DOI: http://dx.doi.org/10.15678/EBER.2017.050110 


\section{INTRODUCTION}

Family businesses (FBs), playing a crucial role in both developed and emerging economies (LaPorta et al., 1999), are increasingly active in international markets. BenavidesVelasco et al. (2011, p. 51) notice that "the traditional family business model of growing organically within a geographic region is rapidly becoming outdated as customers, suppliers and even employees spread across the globe". Therefore, it becomes important to study the phenomenon of family business internationalisation in order to understand how the specific features of family firms, such as their ownership structure and the composition of top management team (TMT), shape the internationalisation process.

Family business literature has been traditionally focused on issues related to succession planning and professionalisation of management, such as intergenerational conflicts, leadership and power transfer or the impact of the owners' characteristics on the outcome of the succession process (Benavides-Velasco et al., 2011). Compared to these prominent topics, internationalisation of $\mathrm{FBs}$ has received relatively less attention, as evidenced by recent reviews conducted by Kontinen \& Ojala (2010) and Pukall \& Calabro (2014). The extant literature on family firms' internationalisation yields ambiguous results, which can be explained by a number of factors. First, due to the relatively early stage of development of this domain, research is fragmented, with most studies exploring the differences between family and nonfamily businesses, taking into consideration variables, grounded in different theoretical frameworks. These studies often do not account for the fact that 'familiness' is a heterogeneous concept, with family (versus nonfamily) ownership and family (versus nonfamily) management being two dimensions which need to be studied independently (Carney, Van Essen, Gedajlovic, \& Heugens, 2015).

Second, although the contributions from International Business (IB) and family business literature overlap, they are not integrated, as studies in family business internationalisation often ignore IB theories (Kontinen \& Ojala, 2010). Moreover, they do not differentiate between different dimensions of internationalisation, typically focusing only on export intensity (Calabrò et al., 2013).

The objective of this paper is to close the research gaps in the extant literature, by answering the following question: How do the ownership structure and the management configuration of family firms contribute to different dimensions of firm internationalisation? In order to answer this question we conduct a quantitative study of family firms from seven European countries (Austria, France, Germany, Hungary, Italy, Spain, UK), based on a EU-EFIGE/Bruegel-UniCredit dataset (Altomonte \& Aquilante, 2012).

The paper is structured as follows. We first discuss the theoretical framework and research hypotheses. In the following section, we outline the method of the study. Next, we present the results of the quantitative analysis. The paper concludes with a discussion on the implications and limitations of the findings.

\section{LITERATURE REVIEW}

\section{The Role of 'Familiness' in Firm's Strategy}

'Familiness' may have both positive and negative effects on firm's competitive position, including its ability to compete in foreign markets. Four theoretical lenses (De Massis, Frat- 
tini, Pizzurno, \& Cassia, 2015): resource-based view, agency theory, stewardship theory and behavioural theory provide an understanding of how 'familiness' matters to firm strategy.

Under the resource-based view (RBV), family firms are a unique bundle of resources and capabilities (Barney, 1991), arising from "the interaction between the family, its individual members and the business" (Habbershon \& Williams, 1999, p. 11). This interaction shapes human, social and financial capital of family firms (Colli, García-Canal, \& Guillén, 2013; Sirmon \& Hitt, 2003).

On a negative side, family firms have a preference towards employing family members, regardless of their competence. The lack of international experience of family managers and resistance towards entering foreign markets have been considered to be important barriers to internationalisation (Gallo \& Pont, 1996). Moreover, the financial capital of family firms is often limited, which may pose a significant barrier to internationalisation.

On a positive side, human capital family firms may be enhanced by extraordinary commitment, intimate relationships and effective mechanisms to transfer tacit knowledge (Sirmon \& Hitt, 2003). In a study of Spanish and Italian multinationals, Colli et al. (2013) found that the family acted as a "repository of (...) accrued experience" (Colli et al., 2013), thus enhancing the internationalisation process. While the financial capital of family firms may be limited, it is also 'patient', i.e. it does not require shortterm results and therefore it enhances strategies which may bring results in the long run (Sirmon \& Hitt, 2003). Moreover, a unique characteristic of family firms is their ability to leverage the family structure for the sake of the business.

Agency theory analyses the outcomes of the separation of ownership and control functions. In companies run by hired managers, divergent interests and asymmetric information of owners and managers create agency problems (Jensen \& Meckling, 1976). Hired managers are more inclined to focus on short-term goals and often act for the sake of acting, just to signal their managerial competences to the owners. The agency problem can be mitigated through a high level of the ownership concentration and the participation of managers in the capital structure (Shleifer \& Vishny, 1997). The extant literature reveals that the concentration of ownership facilitates control over the management and protects the firm against excessive diversification (Amihud \& Lev, 1981), but at the same time, it reduces managerial initiative (Aghion \& Tirole, 1997) and decreases risk propensity (Burkart, Gromb, \& Panunzi, 1997). Moreover, a high level of concentration of ownership in family firms may create incentives for large shareholders to use their controlling position in order to extract private benefits at the expense of smaller shareholders (Arosa, Iturralne, \& Maseda, 2010).

In owner-managed firms the agency problem does not exist, since ownership and control functions are aligned (Jensen \& Meckling, 1976). This is often the case of family firms, where business and personal goals overlap. Moreover, the agency theory argues that family businesses are risk-averse, since a significant proportion of the owner's / family's wealth is invested in the business and the investment is typically not diversified (Fama \& Jensen, 1985).

Stewardship perspective argues that managers do not necessarily act in an opportunistic, individualistic and self-serving way (Davis, Schoorman, \& Donaldson, 1997). Instead, this perspective depicts managers as "collectivist, pro-organizational and trustworthy" (Davis et al., 1997, p. 20). The stewardship orientation is determined by three individual dimensions: motivation (i.e. people motivated by higher-order needs and intrinsic factors are more inclined to act as stewards); identification (i.e. people who have high identification with their 
organisations are more inclined to act as stewards) and power (people who use personal power instead of institutional power are more inclined to act as stewards). Moreover, the emergence of stewardship relationship is more likely in involvement-oriented situations (as opposed to control-oriented situations). Extant studies reveal that family firms often develop stewardship relationships, materialised in participative decision-making, sharing of control in firm governance and reciprocal altruism (Eddleston \& Kellermanns, 2007).

Behavioral theory, emphasising the psychological drivers of firm strategy, adds another perspective to the debate on the motivation and risk-propensity of family firms. Gomez-Mejia et al. (2007) revealed that family firms were willing to bear financial losses and a greater probability of failure in order to maintain family control. Therefore, they may be risk-willing and risk-adverse at the same time, since their main motivation is the preservation of socioemotional wealth, defined as "non-financial aspects of the firm that meet the family's affective needs, such as identity, the ability to exercise family influence, and the perpetuation of the family dynasty" (Gómez-Mejía et al., 2007, p. 106).

This section outlined theoretical reasons to argue that family firms have unique characteristics which may affect their strategic actions, including their internationalisation process. In the next section we provide an overview of studies on internationalisation of family firms and we formulate research hypotheses.

\section{The Internationalisation of Family Firms}

IB literature points to the fact that firms entering foreign markets face a "liability of foreignness", that is an additional cost arising from the unfamiliarity of the local environment. The Uppsala model describes internationalisation as a series of incremental decisions driven by experiential learning (Johanson \& Vahlne, 1977). The internationalisation develops along two dimensions: commitment to foreign markets (i.e. firms start their international expansion with low-commitment modes of entry, subsequently increasing their involvement abroad, a pattern labelled "establishment chain") and distance (i.e. firms start their international expansion with countries close to the domestic market in terms of psychic distance, defined as "factors that make it difficult to understand foreign environments" (Johanson, Vahlne, 2009, p. 1412). In an updated version of this model, Johanson \& Vahlne (2009) point to the importance of networks in the internationalisation process, arguing that a firm which enters a foreign market where it has no network connections, suffers from the "liability of outsidership", which adds to the "liability of foreignness".

A number of studies compared the internationalisation process of family and nonfamily businesses. This stream of research showed that the former have lower export intensity and propensity (Fernández \& Nieto, 2005) and that they internationalise later and more slowly (Gallo \& Pont, 1996). In an early study on Spanish firms, Gallo and Estape (1992) reveal that compared to nonfamily firms, family firms are less prone and slower to enter foreign markets. A similar result was obtained by Okoroafo (1999) who studied family firms from Ohio. He finds that family businesses are reluctant to actively engage in foreign markets. They do not monitor foreign markets, rarely source from foreign markets and, if they do not get involved in foreign countries in the first or second generation, they are unlikely to do it later on. However, there are studies revealing that there is no difference in the internationalisation performance between family- and non-family businesses (Crick et al., 2006; Graves \& Thomas, 2006). There is also a substantial group of studies indicating a positive impact of "familiness" on firm internationalisation. These studies support 
the notion that family businesses have entrepreneurial drive, since their owners and managers are inclined to take risks (Calabro, Mussolino \& Husse, 2009). Zahra (2003), based on a sample of 409 U.S. manufacturing firms, finds that family ownership has a positive impact on the scale and scope of foreign sales. Wach (2015), based on a sample of 355 internationalised firms from Poland, revealed that family firms internationalised faster than non-family firms. Daszkiewicz \& Wach, based on a sample of 216 Polish firms, observed that family firms had a more active attitude towards foreign markets and that their main motivation in internationalisation was market-seeking. They were also less prone to use advanced modes of foreign market entry than non-family firms.

Inconsistencies in the research focused on comparing family and nonfamily businesses may result from the fact that the concept of "family business" is heterogeneous (Carney et al., 2015). Two dimensions: family ownership and family involvement in management are typically used to assess the 'familiness' of a firm.

A number of studies have examined the relationship between family ownership (measured with a percentage of shares possessed by a family) and internationalisation. The ownership structure is important to firm's strategy for at least two reasons: it influences the firm's access to resources (Shrader \& Simon, 1997) and it has an impact on the firm's propensity to take risks (Thomsen \& Pedersen, 2000).

Graves \& Thomas (2008), based on a study of Australian firms, conclude that large stakes in the capital may enable families to finance foreign expansion from internal funds, generated from the domestic market. On the other hand, in their study of Indian automotive and pharmaceutical companies, Bhaumik et al. (2010) provide evidence on the negative influence of $100 \%$ family ownership on the internationalisation. In his study of US manufacturing firms, Zahra (2003) finds that closely held family businesses had a lower level of internationalisation, but this was not the case for other types of family businesses. Sciascia et al. (2012), based on a study of US family firms, reveal that the relationship between family ownership and internationalisation is curvilinear (J-shaped), with export intensity attaining the highest level at the moderate level of family ownership. Arregle et al. (2012), based on Swedish family firms, revealed that external involvement in governance (i.e. external ownership and external boards of directors) enhances internationalisation. Lin (2012), based on a study of publicly listed firms in Taiwan, revealed that a high level of family ownership was negatively associated to the scope of firm internationalisation, as well as the regular rhythm of firm internationalisation. Naldi \& Nordqvist (2008), based on a sample of Swedish family firms, found that external ownership was positively associated with both the scale and the scope of internationalisation. Transferring part of the equity to owners unrelated to the family (i.e. nonfamily ownership), provides families with new resources and often disrupts stability, enhancing more risky strategies (Naldi \& Nordqvist, 2008). Therefore, we formulate the following hypothesis:

H1: There is a positive relationship between the inclusion of non-family ownership and internationalisation of family firms.

While the extant literature suggests that the presence of shareholders from outside the family influences firm strategy, including firm internationalisation (e.g. Fernandez \& Nieto, 2005), the very nature of this influence depends on the type of the external shareholder. For example, owners with a predominantly financial perspective, although not involved in strategic decision-making, bring a 'professionalization impetus' to the company, 
as they require high reporting standards (Kaplan \& Stromberg, 2001). Strategic investors, in turn, bring intangible resources (e.g. know-how). Foreign investors enhance the knowledge and understanding of international markets. Moreover, they provide access to business networks and facilitate communication with other local stakeholders in the foreign markets. This may be particularly relevant to family firms, which often suffer from the lack of resources and capabilities, as well as foreign experience (and network ties in foreign markets). Calabrò et al. (2013), based on a sample of Norwegian firms, find that foreign investors' ownership positively relates to the level of foreign sales and that this relationship is further moderated by family involvement, so that it is stronger for family businesses compared to non-family businesses. We argue that foreign ownership, that is the inclusion of foreign investors in the capital structure, can help family firms to increase their international orientation and to obtain resources necessary for internationalisation.

Therefore, we formulate the following hypothesis:

H2: There is a positive relationship between foreign ownership and internationalisation of family firms.

Owner-CEO in family firms may be motivated by the preservation of the socioemotional wealth (Gómez-Mejía i in., 2007), thus avoiding risks that would endanger the family's control over the business. Moreover, according to the stewardship perspective, owner-CEO would have a long-term orientation and a strong identification with the firm as a social entity. Extant studies reveal that owner-CEOs are unwilling to take actions which would endanger the firm's reputation for the sake of shortterm results (e.g. Zapkau, Schwens, \& Kabst, 2014).

Zahra (2003) reveals that owner-managers of family firms are reluctant towards aggressive entering many foreign markets. Instead, they prefer to maximise revenues from a limited scope of markets. Calabro et al. (2013) find a negative relationship between the CEO ownership and the internationalisation of Norwegian firms. They argue that owners-CEO favor a conservative approach to internationalisation, since they aim at protecting their wealth and minimise competitive and income stream uncertainty. Therefore, we formulate the following hypothesis:

H3: There is a negative relationship between the CEO ownership and the internationalisation of family firms.

Professionalisation of management is one of the main challenges for family firms. Family firms have a strong preference towards employing family members, regardless of their competences. Family managers often do not have international experience and are resistant towards entering foreign markets (Gallo \& Pont, 1996). In one of the first studies on the internationalisation of family firms, Okoroafo (1999) argued that lower levels of the internationalisation of family firms result from lower managerial capabilities of family business leaders. In family business literature, the inclusion of nonfamily managers in the TMTs has been regarded as a sign of bringing new and unique knowledge to the team (Vanderkhof, 2015). Naldi \& Nordkvist (2008) found that increased representation of external (i.e. non-family) board members enhanced the scope of internationalisation. Therefore, we formulate the following hypothesis:

H4: There is a positive relationship between the inclusion of nonfamily managers and the internationalisation of family firms. 
The hypothesised relationships are presented in Figure 1.

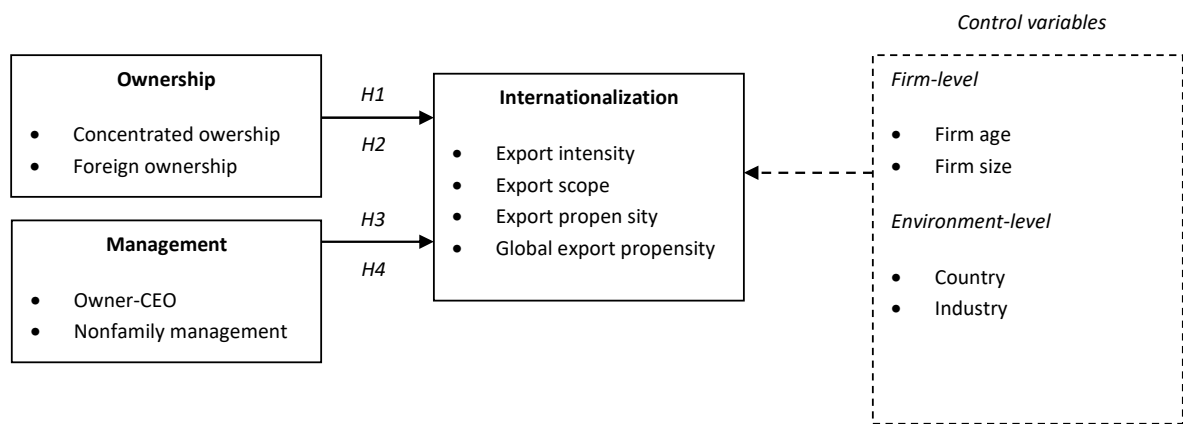

Figure 1. Analytical framework Source: own elaboration.

\section{MATERIAL AND METHODS}

\section{Data Collection and Sample}

We use the EU-EFIGE/Bruegel-UniCredit dataset, a firm-level database constructed within the project European Firms in a Global Economy: internal policies for external competitiveness (EFIGE). This project was carried out by a number of academic institutions ${ }^{1}$, in cooperation with national central banks and OECD and received support from the Directorate General Research of the European Commission through the 7th Framework Programme. The database includes 14,750 companies (above 10 employees) from 7 countries (Austria, France, Germany, Italy, Spain, Hungary, UK) and covers approximately 150 items, divided into six areas: structure of the firm, workforce, investment \& technology, internationalisation, market structure, financial structure. The country-level samples are representative for manufacturing firms. Data were collected in 2010 by a specialised agency (GFK Eurisko), using the CATI method. The questionnaire covered data for 2008, with several recall questions concerning three previous years (2005-2007) (Altomonte \& Aquilante, 2012). This comprehensive dataset was used in prior studies to examine a number of strategic choices made by European firms (e.g. Brzozowski \& Cucculelli, 2016).

In the extant literature there is no consensus on the definition of the family firm (Benavides-Velasco et al., 2011). Following previous studies (Pukall \& Calabro, 2014), we define family business as a firm with family control and a significant involvement of family in the top management team. Therefore, from the EFIGE dataset we select firms which meet two criteria: 1) the firm responds 'yes' to a question 'Is your firm directly or indirectly controlled by an individual or family-owned entity?' and 2) the firm provides a value other than 0 to a question 'Entrepreneurs/Executives (included middle management) who are related to the family which owns the company'. We identify 6,957 family firms in the dataset (see table 1 ), of which 4,472 are exporters.

\footnotetext{
${ }^{1}$ Universidad Carlos III de Madrid, Centre for Economic Policy Researcher (CEPR), The Institute of Economics of Hungarian Academy of Sciences, Institute for Applied Economic Research (IAW) , Centro Studi Luca d'Agliano (Ld'A), UniCredit, Centre d'Etudes Prospectives et d'Informations Internationales (CEPII)
} 
Table 1. Sample characteristics

\begin{tabular}{|l|r|r|r|r|r|r|r|r|}
\hline \multirow{2}{*}{ Number of employees } & \multicolumn{7}{|c|}{ Country } & \multirow{2}{*}{ Total } \\
\cline { 2 - 10 } & AUT & FRA & GER & HUN & ITA & \multicolumn{1}{|c|}{ SPA } & UK & \\
\hline Above 250 & 3 & 17 & 23 & 2 & 20 & 39 & 47 & 151 \\
\hline $50-249$ & 31 & 184 & 186 & 24 & 195 & 226 & 172 & 1018 \\
\hline $10-49$ & 132 & 1013 & 948 & 187 & 1492 & 1220 & 796 & 5788 \\
\hline Total & 166 & 1214 & 1157 & 213 & 1707 & 1485 & 1015 & 6957 \\
\hline
\end{tabular}

Source: own elaboration based on EFIGE dataset

\section{Measures}

In this study we focus on export, which requires a relatively low commitment and risk (Johanson \& Vahlne, 2009), and therefore constitutes the most common mode of entry to foreign markets among family firms (Fernández \& Nieto, 2005). Following Pukall \& Calabro's (2014) call for a multidimensional assessment of the internationalisation of family firms, we use four variables, corresponding to different dimensions of the internationalisation process. First, we study export propensity, using a dichotomous variable (denominated 'exporter' in the EFIGE dataset) which takes value of 1 if the firm is a direct exporter in 2008 or has been exporting in years before 2008. Second, we study export intensity with a continuous variable measured with the percentage of sales outside the home country. Third, we study export scope, i.e. the number of countries to which the company exports its products. Fourth, we study the propensity to export to distant countries, using a dichotomous variable global export propensity, which takes value of 1 if the firm is exporting to China, India or other Asian countries, or USA, Canada or Central or South America.

As indicated in the research hypotheses, the study investigates the impact of four dimensions relating to the ownership and management in family firms: the concentration of ownership, foreign ownership, owner-CEO and the involvement of nonfamily managers in firm management. The concentration of ownership is measured as a dichotomous variable (concentration), taking value of 1 if the family controls $100 \%$ of the capital. Foreign ownership is measured at two levels, with two dichotomous variables: minority foreign ownership (foreign ownership above $5 \%$ and below 51\%), controlling foreign ownership (foreign ownership above 51\%). Owner-CEO is a dichotomous variable, taking value of 1 if the CEO is 'the individual who controls the firm or a member of the controlling family'. Following the extant family business literature (e.g. Vanderkhof et al., 2015), we measure the involvement of nonfamily managers with a dichotomous variable (nonfamily managers) taking value of 1 if at least 1 TMT member does not belong to the controlling family.

The study employs four control variables. First, we control the country, using the following dummy variables: Austria $(A U T)$, France $(F R A)$, Germany $(G E R)$, Hungary $(H U N)$, Italy (ITA), Spain (SPA), United Kingdom (UK). ITA is not included in the regression models, as it represents a reference level for the interpretation of the results for other country variables. Second, we control for industry effects, using the following dummy variables: traditional, high-tech, specialised, economies of scale. This classification, offered in the EFIGE dataset, follows Pavitt's taxonomy (Pavitt, Robson, \& Townsend, 1989) and it is based on the NACE code of firm (3-digits). Traditional is not included in the regression models, as it represents a reference level for the interpretation of the results for other 
industry variables. Third, in order to account for size-related effects, we control for firm size and we measure this variable using the natural logarithm of the number of employees. Fourth, we control for firm age, since previous studies provide evidence that the older the family firm, the higher its internationalisation level and that new generations of family managers positively influence the internationalisation process (Menendez-Requejo, 2005). In order to preserve anonymity of firms, the EFIGE dataset provides only categorial variables for the year of establishment ( $<6$ years; $6-20$ years; $>20$ years). Therefore, we use the following dummy variables: young (less than 6 years); middle-aged (6-20 years); old (more than 20 years). Middle-aged is not included in the regression models.

Below we present descriptive statistics and correlation matrix for continuous variables included in the study. As we can see from the table, on average, the family exporters included in the sample derive $29.48 \%$ of sales from foreign markets and export to 10.35 countries.

Table 2. Correlations and descriptive statistics

\begin{tabular}{|c|c|c|c|}
\hline & $\begin{array}{l}\text { Export intensity } \\
\text { (only exporters) }\end{array}$ & $\begin{array}{c}\text { Export scope } \\
\text { (only exporters) }\end{array}$ & $\begin{array}{c}\text { Size } \\
\text { (full sample) }\end{array}$ \\
\hline \multicolumn{4}{|c|}{$r$-Pearson correlations } \\
\hline Export intensity & 1 & - & - \\
\hline Export scope & $0.435 *$ & 1 & - \\
\hline Size & $0.153^{*}$ & $0.330^{*}$ & 1 \\
\hline \multicolumn{4}{|c|}{ Descriptive statistics } \\
\hline Mean & 29.477 & 10.349 & 3.321 \\
\hline SD & 26.730 & 14.337 & 0.755 \\
\hline Minimum & 0.000 & 1.000 & 2.302 \\
\hline Maximum & 100.000 & 150.000 & 6.215 \\
\hline
\end{tabular}

${ }^{*} p<0.05$

Source: own calculations in SPSS.

\section{RESULTS AND DISCUSSION}

A regression analysis was performed to test the conceptual model (Figure 1). In order to test our research hypotheses, we used regression analysis.

For continuous dependent variables (i.e. export intensity and export scope), we used linear regression models. We chose linear regression, without trying to fit curvilinear relationships, for three reasons. First, since the tested independent variables are dichotomous, we are unable to model different shapes of our relationships between, for example, family ownership and export intensity. Second, we obtained a reasonable model fit, and we concluded that linear regression was good enough. Third, in choosing linear models, we followed other studies investigating the relationship between the ownership structure, the composition of TMTs and the internationalisation of FBs (e.g. Lin, 2012; Naldi \& Nordqvist, 2008).

Table 3 presents linear regression estimates for export intensity and export scope. We examined potential multi-colinearity problems by calculating the value inflation factors (VIF's). The VIFs for all the variables were below 1.60, that is lower than the recommended threshold (Neter et al., 1996). We therefore conclude that multi-collinearity is not a concern in this study. Moreover, we tested the autocorrelation of residuals (Durbin-Watson test) 
and the normality of residuals (Kolmogorov-Smirnov test). We analysed the plots of residuals versus predicted values to check the assumptions of homoscedasticity and linearity.

Both models have a relatively low coefficient of determination (adjusted R2). We explain these results by the fact that both export intensity and export scope are influenced by many other factors, such as firm performance, product diversification or export experience (e.g. Lin, 2012). Due to the unavailability of data, we were unable to control many of these factors. However, despite a low level of determination, both models are statistically significant, thus indicating that the goodness of fit for both models is sufficient for the purpose of hypotheses testing.

Table 3. Linear regression analysis for export intensity and export scope

\begin{tabular}{|c|c|c|c|c|c|c|c|c|c|c|}
\hline & \multicolumn{5}{|c|}{$\begin{array}{l}\text { Model 1. Export intensity } \\
\text { (only exporters) }\end{array}$} & \multicolumn{5}{|c|}{$\begin{array}{l}\text { Model 2. Export scope } \\
\text { (only exporters) }\end{array}$} \\
\hline & Beta & $\mathbf{T}$ & Sig. & Tolerance & VIF & Beta & $\mathbf{T}$ & Sig. & Tolerance & VIF \\
\hline AUT & -0.024 & -1.258 & 0.208 & 0.906 & 1.104 & -0.054 & -2.864 & 0.004 & 0.906 & 1.104 \\
\hline FRA & -0.144 & -6.868 & 0.000 & 0.769 & 1.300 & -0.078 & -3.866 & 0.000 & 0.770 & 1.299 \\
\hline GER & -0.148 & -6.467 & 0.000 & 0.643 & 1.556 & $\mid-0.030$ & -1.353 & 0.176 & 0.643 & 1.554 \\
\hline HUN & 0.029 & 1.501 & 0.133 & 0.878 & 1.138 & -0.090 & -4.740 & 0.000 & 0.878 & 1.139 \\
\hline SPA & -0.166 & -7.383 & 0.000 & 0.671 & 1.490 & -0.093 & -4.266 & 0.000 & 0.671 & 1.489 \\
\hline UK & -0.129 & -5.627 & 0.000 & 0.647 & 1.546 & -0.028 & -1.285 & 0.199 & 0.656 & 1.525 \\
\hline Scale & -0.020 & -0.997 & 0.319 & 0.869 & 1.151 & 0.050 & 2.642 & 0.008 & 0.871 & 1.148 \\
\hline Specialized & 0.100 & 5.090 & 0.000 & 0.873 & 1.145 & 0.097 & 5.111 & 0.000 & 0.874 & 1.144 \\
\hline High-tech & 0.021 & 1.094 & 0.274 & 0.941 & 1.063 & 0.094 & 5.100 & 0.000 & 0.941 & 1.063 \\
\hline Old & 0.024 & 1.200 & 0.230 & 0.840 & 1.191 & 0.083 & 4.250 & 0.000 & 0.839 & 1.192 \\
\hline Young & 0.015 & 0.777 & 0.437 & 0.891 & 1.122 & 0.001 & 0.066 & 0.947 & 0.891 & 1.122 \\
\hline Size & 0.117 & 5.970 & 0.000 & 0.879 & 1.138 & 0.259 & 13.627 & 0.000 & 0.878 & 1.139 \\
\hline Owner-CEO & -0.010 & -0.556 & 0.578 & 0.966 & 1.036 & -0.027 & -1.496 & 0.135 & 0.965 & 1.036 \\
\hline Concentration of ownership & 0.029 & 1.474 & 0.141 & 0.884 & 1.132 & -0.006 & -0.340 & 0.734 & 0.884 & 1.132 \\
\hline Nonfamily managers & 0.059 & 2.536 & 0.011 & 0.632 & 1.582 & 0.061 & 2.732 & 0.006 & 0.634 & 1.578 \\
\hline Minority foreign ownership & 0.051 & 2.759 & 0.006 & 0.989 & 1.011 & 0.079 & 4.396 & 0.000 & 0.989 & 1.012 \\
\hline Controlling foreign ownership & 0.074 & 3.956 & 0.000 & 0.976 & 1.025 & 0.02 & 1.458 & 0.145 & 0.975 & 1.026 \\
\hline \multicolumn{11}{|l|}{ Model summary } \\
\hline R2 & 0.070 & - & - & - & - & - & 0.134 & - & - & - \\
\hline Adj R2 & 0.064 & - & - & - & - & - & 0.129 & - & - & - \\
\hline $\mathrm{F}$ & 12.219 & - & - & - & - & - & 24.909 & - & - & - \\
\hline Sig. Of $\mathrm{F}$ & 0.000 & - & - & - & - & - & 0.000 & - & - & - \\
\hline
\end{tabular}

Source: own calculations in SPSS.

Hypothesis 1 predicts a negative relationship between the concentration of ownership and the internationalisation of family firms. We find strong support for this hypothesis in relation to export propensity (model 3), i.e. the concentration of ownership in family firms negatively influences export propensity $(p<0.001)$. We also find some support for this hypothesis, although at a low significance level $(p<0.1)$ in relation to global export propensity (model 4). We find no significant relationship between the concentration of ownership and export intensity (model 1) and export scope (model 2). 
Hypothesis 2 predicts a positive relationship between foreign ownership and the internationalisation of family firms. We measure foreign ownership at two levels (minority versus controlling ownership), using two dichotomous variables. We find support for the relationship between minority foreign ownership and all dimensions of internationalisation: export intensity $(p<0.01)$ (model 1$)$, export scope $(p<0.001)$ (model 2$)$, export propensity $(p<0.05)$ (model 3 ) and global export propensity $(p<0.01)$ (model 4$)$. We find support for the relationship between controlling foreign ownership and: export intensity (model 1 ) $(p<0.001)$ and export propensity $(p<0.01)$ (model 3$)$. We find no significant relationship between controlling foreign ownership and export scope (model 2) and a weak relationship $(p<0.1)$ between controlling foreign ownership and global export propensity (model 4).

For two other dimensions of internationalisation: export propensity and propensity to enter more distant markets (global export propensity), we use binary logistic regression analysis. This technique is suitable if the dependent variable is dichotomous and is widely used in IB literature for modeling export propensity (e.g. Zhao \& Zou, 2002). Table 4 presents binary logistic regression estimates.

Table 4. Logistic regression analysis for export propensity and global export propensity

\begin{tabular}{|c|c|c|c|c|c|c|}
\hline & \multirow{2}{*}{\multicolumn{3}{|c|}{$\begin{array}{l}\text { Model } 3 \text { - export propensity } \\
\text { (full sample) }\end{array}$}} & & & \\
\hline & & & & \multicolumn{3}{|c|}{$\begin{array}{l}\text { Model 4-global export propensity } \\
\text { (full sample) }\end{array}$} \\
\hline & B & $\operatorname{Exp}(B)$ & Sig. & B & $\operatorname{Exp}(B)$ & Sig. \\
\hline AUT & 0.037 & 1.038 & 0.863 & -1.376 & 0.253 & 0.000 \\
\hline FRA & -0.937 & 0.392 & 0.000 & -1.050 & 0.350 & 0.000 \\
\hline GER & -1.031 & 0.357 & 0.000 & -1.068 & 0.344 & 0.000 \\
\hline HUN & -0.423 & 0.655 & 0.023 & -2.088 & 0.124 & 0.000 \\
\hline SPA & -0.621 & 0.538 & 0.000 & -0.863 & 0.422 & 0.000 \\
\hline UK & -0.937 & 0.392 & 0.000 & -0.409 & 0.665 & 0.001 \\
\hline Scale & -0.010 & 0.990 & 0.888 & -0.064 & 0.938 & 0.463 \\
\hline Specialized & 0.884 & 2.422 & 0.000 & 0.829 & 2.292 & 0.000 \\
\hline High-tech & 0.673 & 1.960 & 0.000 & 0.802 & 2.230 & 0.000 \\
\hline Old & 0.403 & 1.496 & 0.000 & 0.417 & 1.517 & 0.000 \\
\hline Young & -0.202 & 0.817 & 0.120 & 0.134 & 1.144 & 0.404 \\
\hline Size & 0.382 & 1.465 & 0.000 & 0.492 & 1.635 & 0.000 \\
\hline Owner-CEO & -0.154 & 0.858 & 0.311 & -0.341 & 0.711 & 0.030 \\
\hline Concentration & -0.339 & 0.712 & 0.000 & -0.173 & 0.842 & 0.060 \\
\hline Nonfamily managers & 0.491 & 1.634 & 0.000 & 0.418 & 1.519 & 0.000 \\
\hline Minority foreign ownership & 0.995 & 2.704 & 0.012 & 0.812 & 2.252 & 0.004 \\
\hline Controlling foreign ownership & 1.021 & 2.776 & 0.005 & 0.490 & 1.632 & 0.098 \\
\hline Stała & -0.788 & 0.455 & 0.005 & -2.163 & 0.115 & 0.000 \\
\hline \multicolumn{7}{|l|}{ Omnibus Tests of Model Coefficients } \\
\hline Chi-square & 546.049 & - & - & 548.332 & - & - \\
\hline Sig. & 0.000 & - & - & 0.000 & - & - \\
\hline \multicolumn{7}{|l|}{ Hosmer and Lemeshow test } \\
\hline Chi-square & 12.178 & - & - & 3.252 & - & - \\
\hline Sig. & 0.143 & - & - & 0.918 & - & - \\
\hline \multicolumn{7}{|l|}{ Model summary } \\
\hline-2 Log likelihood & 6637.644 & - & - & 5464.471 & - & - \\
\hline Cox \& Snell R Squared & 0.095 & - & - & 0.095 & - & - \\
\hline Nagelkerke R Squared & 0.130 & - & - & 0.143 & - & - \\
\hline$\%$ correctly classified (Step 0) & 63.600 & - & - & 76.200 & - & - \\
\hline \% correctly classified (Full model) & 66.600 & - & - & 77.1 & - & - \\
\hline
\end{tabular}

Source: own calculations in SPSS. 
Hypothesis 3 a negative relationship between the CEO ownership and the internationalisation of family firms. Our findings support this relationship in terms of global export propensity $p<0.05$ (model 4 ), i.e. owners-CEO are less prone to engage in global exporting. We find no support for the relationship between CEO ownership and internationalisation in terms of export intensity (model 1), export scope (model 2) and export propensity (model 3).

Hypothesis 4 predicts a positive relationship between the involvement of external managers and the internationalisation of family firms. We find support for this hypothesis in terms of all studied dimensions of internationalisation: export intensity $(p<0.05)$, export scope $(p<0.01)$, export propensity $(p<0.001)$ and global export propensity $(p<0.001)$.

\section{CONCLUSIONS}

To broaden our understanding of the determinants of family firm internationalisation, we examined the roles of ownership (i.e. the concentration of ownership, foreign ownership) and management (i.e. the involvement of nonfamily managers, owner CEO). The general conclusion which can be drawn from the study is that external influences within both ownership and management enhance firm's internationalisation efforts. This conclusion is consistent with the most recent publications addressing the heterogeneity of family firms (Calabro et al., 2012; Sciascia et al., 2012).

Our findings have a number of theoretical implications. While we find support for the notion that the inclusion of outsiders (both in terms of ownership and management) enhances internationalisation, we shed more light on the specific effects of this mechanism on different dimensions of internationalisation. First, we find that the concentration of ownership within the family hinders the propensity to export, but it has no effect on export intensity and export scope. Therefore, we may conclude that concentrated ownership constitutes at first an important barrier to internationalisation, preventing family firms to enter foreign markets. However, concentrated ownership does not affect export performance of family firms which are already active abroad.

Second, we find support for the notion that foreign ownership contributes to firm internationalisation. Interestingly, the impact of minority foreign ownership is more pronounced than the controlling foreign ownership. While the former affects all the dimensions of internationalisation, the latter has no effect on export scope and global export propensity. We may explain this result with the subsidiary mandate framework, offered in IB literature (e.g. Birkinshaw, 1996). This framework suggests that the nature of subsidiary responsibilities depends on the MNE overall strategy, and more specifically, its expectations as to the role of this subsidiary in the MNE value chain (Young, Tavares, 2004). Thus, subsidiaries of MNEs have different strategic mandates, which often include an export mandate (Filatotchev, Stephan, \& Jindra, 2008). Filatotchev et al. (2008) argue that the ability of local managers to undertake export is dependent upon the foreign investors' ownership and control over decisions made by the subsidiary. In a study of foreign invested firms in CEE, they find that export intensity of local firms is influenced by foreign investors' ownership and strategic control and that these two attributes complement each other in terms of their impact on export behaviours. In relation to our findings we may conclude that while local subsidiaries of MNEs actively engage in export they do not expand to distant locations, as it would probably not be coherent with the MNE overall strategy. 
Third, in line with the results of previous studies (e.g. Naldi \& Nordqvist, 2008), we find support for the notion that the involvement of nonfamily managers enhances internationalisation. Fourth, we find that owner-CEO does not necessarily hinder the internationalisation efforts, as the significance of this variable is observed only in relation to global exporting. We may explain this result by the unwillingness of owner-CEO to enter psychically distant markets. Miller, Le Breton-Miller and Scholnick (2008) found that family firms differed from non-family businesses in terms of the type of connections they developed with both employees and customers. In family businesses these relationships are very close, which may be particularly demanding in an international context, especially psychically distant markets (Kontinen \& Ojala, 2010).

Based on our findings, we are able to formulate some recommendations to family business managers. Our results indicate that in order to expand abroad, family firms should consider including outsiders (i.e. nonfamily investors and nonfamily managers) in their ownership structure and TMT external influences. While nonfamily ownership is particularly relevant in the initial phase of internationalisation, influencing export propensity; nonfamily managers enhance all dimensions of internationalisation (i.e. export propensity, scope and intensity, as well as exporting to distant markets). Therefore, a practical implication of our study is that in order to accelerate the internationalisation of their businesses, family firm owners should not only seek for external (i.e. nonfamily) capital, but also be open to nonfamily influence in the management team.

Our findings are tempered by some limitations. First, as we use cross-sectional data, we are unable to test the effects of the ownership structure and management on internationalisation in a strict sense. While there are conceptual arguments in favor of these variables affecting internationalisation, the other causal direction is possible. For example, as family firms decide to expand abroad, they may seek the professionalisation of management, thus opening their management teams to non-family managers. Second, as we aimed at providing cross-country evidence, we used a large dataset developed within the EFIGE project. While this approach has many advantages, allowing for the use of fully comparable, representative data, it does not allow for a nuanced measurement of variables, due to the unavailability of data. We therefore encourage further research investigating the relationships between different dimensions of 'familiness' and firm internationalisation, preferably in a multi-country context (e.g. advanced versus emerging economies), using more refined measures, reflecting more detailed structure of firm ownership and management.

Some recent studies have dealt with the influence of the national context upon the performance of family firms (e.g. Dow \& McGuire, 2016). Moreover, there is some evidence that patterns of the internationalisation of family firms may be country- or regionspecific. For example, Chung (2014) investigated the phenomenon of semi-globalisation of Asian firms, linking it to specific governance structures of family business groups. We believe that research into the national-level (e.g. cultural, institutional) contingencies of family business internationalisation is a promising area for further research. 


\section{REFERENCES}

Aghion, P., \& Tirole, J. (1997). Formal and Real Authority in Organizations. Journal of Political Economy, 105 (1), 1-29.

Altomonte, C., \& Aquilante, T. (2012). The EU-EFIGE/Bruegel-unicredit dataset. Bruegel working paper (No. 2012/13).

Amihud, Y., \& Lev, B. (1981). Risk Reduction as a Managerial Motive for Conglomerate Mergers. The Bell Journal of Economics, 12(2), 605-617.

Arregle J-L., Naldi L, Nordqvist M. \& Hitt M. (2012). Internationalisation of Family-Controlled Firms: A Study of the Effects of External Involvement in Governance. Entrepreneurship Theory \& Practice, 36(6), 1115-1143.

Barney, J. (1991). Firm Resources and Sustained Competitive Advantage. Journal of Management, 17(1), 99-120.

Benavides-Velasco, C. A., Quintana-García, C., \& Guzmán-Parra, V. F. (2011). Trends in family business research. Small Business Economics, 40(1), 41-57.

Bhaumik, S. K., Driffield, N., \& Pal, S. (2010). Does ownership structure of emerging-market firms affect their outward FDI? The case of the Indian automotive and pharmaceutical sectors. Journal of International Business Studies, 41(3), 437-450.

Birkinshaw, J. (1996). How multinational subsidiary mandates are gained and lost. Journal of International Business Studies, 27, 467-496.

Blanca Arosa, B., Iturralde, T., \& Maseda, A. (2010). Ownership structure and firm performance in non-listed firms: Evidence from Spain. Journal of Family Business Strategy, 1(2), 88-96.

Brzozowski, J., \& Cucculelli, M. (2016). Proactive and Reactive Attitude to Crisis: Evidence from European Firms. Entrepreneurial Business and Economics Review, 4(1), 181-191.

Burkart, M., Gromb, D., \& Panunzi, F. (1997). Large Shareholders, Monitoring, and the Value of the Firm. The Quarterly Journal of Economics, 112(3), 693-728.

Calabrò, A., Mussolino, D. \& Huse, M. (2009). The role of board of directors in the internationalisation process of small and medium sized family businesses. International Journal of Globalisation and Small Business, 3(4), 393-411.

Calabrò, A., Torchia, M., Pukall, T., \& Mussolino, D. (2013). The influence of ownership structure and board strategic involvement on international sales: The moderating effect of family involvement. International Business Review, 22(3), 509-523.

Carney, M., Van Essen, M., Gedajlovic, E. R., \& Heugens, P. P. (2015). What Do We Know About Private Family Firms? A Meta-Analytical Review. Entrepreneurship Theory and Practice, 39(3), 513-544.

Chung, H-M. (2014). The role of family management and ownership on semi-globalization pattern of globalization: The case of family business groups. International Business Review, 23(1), 260-271.

Colli, A., García-Canal, E., \& Guillén, M. F. (2013). Family character and international entrepreneurship: A historical comparison of Italian and Spanish 'new multinationals'. Business History, 55(1), 119-138.

Crick, D., Bradshaw, R., \& Chaudry. S. (2006). Successful internationalising UK family and nonfamily-owned firms: A comparative study. Journal of Small Business and Enterprise Development, 13 (4), 498-512.

Daszkiewicz, N., \& Wach, K. (2014). Motives for Going International and Entry Modes of Family Firms in Poland. Journal of Intercultural Management, 6(2), 5-18. 
Davis, J. H., Schoorman, F. D., \& Donaldson, L. (1997). Toward a Stewardship Theory of Management. The Academy of Management Review, 22(1), 20-47.

De Massis, A., Frattini, F., Pizzurno, E., \& Cassia, L. (2015). Product Innovation in Family versus Nonfamily Firms: An Exploratory Analysis. Journal of Small Business Management, 53(1), 1-36.

Dow, S., \& McGuire, J. (2016), Family matters? A cross-national analysis of the performance implications of family ownership. Corporate Governance - an International Review, forthcoming.

Eddleston, K. A., \& Kellermanns, F. W. (2007). Destructive and productive family relationships: A stewardship theory perspective. Journal of Business Venturing, 22(4), 545-565.

Fama, E. F., \& M. C. Jensen. (1985). Organizational Forms and Investment Decisions. Journal of Financial Economics, 14, 101-119.

Fernandez, Z., \& Nieto, M.J. (2005). Internationalization strategy of small and medium-sized family businesses: Some influential factors. Family Business Review, 18(1), 77-89.

Filatotchev, I., Stephan, J., \& Jindra, B. (2008). Ownership structure, strategic controls and export intensity of foreign-invested firms in transition economies. Journal of International Business Studies, 39(7), 1133-1148.

Gallo, M. A., \& Pont, C. G. (1996). Important Factors in Family Business Internationalisation. Family Business Review, 9(1), 45-59.

Gallo, M.A. \& Estapé, M.J. (1992). Internationalization of the family business. Research paper no. 230, IESE Business School.

Gómez-Mejía, L. R., Haynes, K. T., Núñez-Nickel, M., Jacobson, K. J. L., \& Moyano-Fuentes, J. (2007). Socioemotional Wealth and Business Risks in Family-controlled Firms: Evidence from Spanish Olive Oil Mills. Administrative Science Quarterly, 52(1), 106-137.

Graves, C. \& Thomas, J., (2006).Internationalisation of Australian family businesses: A managerial capabilities perspective. Family Business Review, 19(3), 207-224

Graves, C., \& Thomas, J. (2008). Determinants of the Internationalisation Pathways of Family Firms: An Examination of Family Influence. Family Business Review, 21(2), 151-167.

Habbershon, T. G., \& Williams, M. L. (1999). A Resource-Based Framework for Assessing the Strategic Advantages of Family Firms. Family Business Review, 12(1), 1-25.

Jensen, M. C., \& Meckling, W. H. (1976). Theory of the Firm: Managerial Behavior, Agency Costs and Ownership Structure (SSRN Scholarly Paper No. ID 94043). Rochester, NY: Social Science Research Network.

Johanson, J., \& Vahlne, J.-E. (1977). The Internationalisation Process of the Firm-A Model of Knowledge Development and Increasing Foreign Market Commitments. Journal of International Business Studies, 8(1), 23-32.

Johanson, J., \& Vahlne, J.-E. (2009). The Uppsala internationalisation process model revisited: From liability of foreignness to liability of outsidership. Journal of International Business Studies, 40(9), 1411-1431.

Kaplan, S. N., \& Stromberg, P. (2001). Venture capitalists as principals: Contracting, screening, and monitoring. National Bureau of Economic Research.

Kontinen, T., \& Ojala, A. (2010). The internationalisation of family businesses: A review of extant research. Journal of Family Business Strategy, 1(2), 97-107.

LaPorta, R., Lopez-de-Silanes, F., \& Shleifer, A. (1999). Corporate Ownership Around the World. Journal of Finance, 54(2), 471-517.

Lin, W-T. (2012). Family ownership and internationalization process: internationalization pace, internationalization scope, and internationalization rhythm. European Management Journal, 30, 47-56. 
Miller, D., Le Breton-Miller, I. \& Scholnick, B. (2008). Stewardship vs stagnation: an empirical comparison of small family and non-family businesses. Journal of Management Studies, 45(1), 51-78.

Naldi, L., \& Nordqvist, M. (2008). Family Firms Venturing into International Markets: A Resource Dependence Perspective. Frontiers of Entrepreneurship Research, 28(14), 1-18.

Okoroafo, S. C. (1999). Internationalisation of Family Businesses: Evidence from Northwest Ohio, U.S.A. Family Business Review, 12(2), 147-158.

Pavitt, K., Robson, M., \& Townsend, J. (1989). Technological Accumulation, Diversification and Organisation in UK Companies, 1945-1983. Management Science, 35(1), 81-99.

Pukall, T. J., \& Calabrò, A. (2014). The Internationalisation of Family Firms A Critical Review and Integrative Model. Family Business Review, 27(2), 103-125.

Sciascia, S., Mazzola, P., Astrachan, J. \& Pieper, T. (2012). The role of family ownership in international entrepreneurship: exploring nonlinear effects. Small Business Economics, 38(1), 15-31.

Shleifer, A., \& Vishny, R. W. (1997). A Survey of Corporate Governance. The Journal of Finance, 52(2), 737-783.

Shrader, R. C., \& Simon, M. (1997). Corporate versus independent new ventures: Resource, strategy, and performance differences. Journal of Business Venturing, 12(1), 47-66.

Sirmon, D. G., \& Hitt, M. A. (2003). Managing Resources: Linking Unique Resources, Management, and Wealth Creation in Family Firms. Entrepreneurship Theory and Practice, 27(4), 339-358.

Thomsen, S., \& Pedersen, T. (2000). Ownership structure and economic performance in the largest European companies. Strategic Management Journal, 21(6), 689-705.

Vandekerkhof, P., Steijvers, T., Hendriks, W., Voordeckers, W. (2015). The Effect of Organizational Characteristics on the Appointment of Nonfamily Managers in Private Family Firms: The Moderating Role of Socioemotional Wealth. Family Business Review, 28(2), 104-122.

Wach, K. (2015). Incremental versus Rapid Internationalisation of Firms: Results of Exploratory Investigation from Poland. Entrepreneurial Business and Economics Review, 3(4), 37-48.

Wen-Ting Lin, W-T. (2012), Family ownership and internationalization processes: Internationalization pace, internationalization scope, and internationalization rhythm. European Management Journal, 30 (1), 47-56.

Young, S., Tavares, A.T. (2004). Centralization and autonomy: Back to the future. International Business Review, 13, 215-237.

Zahra, S. A. (2003). International expansion of U.S. manufacturing family businesses: the effect of ownership and involvement. Journal of Business Venturing, 18(4), 495-512.

Zapkau, F. B., Schwens, C., \& Kabst, R. (2014). Foreign Direct Investments and Domestic Employment of German SMEs: The Moderating Effect of Owner Management. Journal of Small Business Management, 52(3), 451-476.

Zhao, H., \& Zou, S. (2002). The Impact of Industry Concentration and Firm Location on Export Propensity and Intensity: An Empirical Analysis of Chinese Manufacturing Firms. Journal of International Marketing, 10(1), 52-71. 


\section{Author}

\section{Aleksandra Wąsowska}

Assistant Professor in the Department of Strategic and International Management at the Faculty of Management, University of Warsaw (UW). She received PhD in Management (UW) and master degrees in Management (UW), Spanish and Portuguese Studies (UW) and Psychology (SWPS University). She gained business experience in multinational companies (Ernst \& Young, BNP Paribas). So far she has published in journals, such as European Journal of International Management or Journal for East European Management Studies. She is the author of chapters in books published by internationally recognized publishers, such as Palgrave Macmillan, Edward Elgar, Wiley. Her scientific interests include decision-making processes in international corporations, internationalisation strategies of companies from emerging markets and the psychological antecedents of international entrepreneurship.

Correspondence to: dr Aleksandra Wąsowska; University of Warsaw; Faculty of Management, ul. Szturmowa 1/3; 02-678, Warsaw, Poland; e-mail: awasowska@wz.uw.edu.pl

\section{Acknowledgements and Financial Disclosure}

This project received funding from the National Science Center through grant no. DEC2011/03/D/HS4/01954.

\section{Copyright and License}

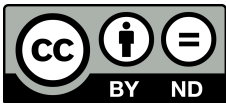

This article is published under the terms of the Creative Commons Attribution - NoDerivs (CC BY-ND 4.0) License http://creativecommons.org/licenses/by-nd/4.0/

Published by the Centre for Strategic and International Entrepreneurship - Krakow, Poland 
